\title{
MODELLING FARMERS' ADAPTATION STRATEGIES FOR CLIMATE CHANGE AND VARIABILITY: THE CASE OF THE LIMPOPO BASIN, SOUTH AFRICA
}

\author{
Glwadys Aymone Gbetibouo **, Rashid M. Hassan² and Claudia Ringler ${ }^{3}$
}

\section{ABSTRACT}

This paper examines climate adaptation strategies of farmers in the Limpopo Basin of South Africa. Survey results show that while many farmers noticed long-term changes in temperature and precipitation, most could not take remedial action. Lack of access to credit and water were cited as the main factors inhibiting adaptation. Common adaptation responses reported included diversifying crops, changing varieties and planting dates, using irrigation, and supplementing livestock feed. A multinomial logit analysis of climate adaptation responses suggests that access to water, credit, extension services and off-farm income and employment opportunities, tenure security, farmers' asset base and farming experience are key to enhancing farmers' adaptive capacity. This implies that appropriate government interventions to improve farmers' access to and the status of these factors are needed for reducing vulnerability of farmers to climate adversities in such arid areas.

Keywords: adaptation, agriculture, climate change and variability, perception

\section{$1 \quad$ INTRODUCTION}

Climate change is expected to have serious environmental, economic and social impacts on South Africa. In particular rural households, whose livelihoods are highly dependent on exploiting their natural resources, are likely to bear the brunt of adverse impacts. The extent to which these impacts are felt depends in large part on the capacity of affected communities to adapt. Without adaptation, climate change would be detrimental, but with adaptation, vulnerability can be significantly reduced (Easterling et al. 1993, Rosenzweig \& Parry 1994, Smith 1996, Mendelsohn 1998, Reilly \& Schimmelpfennig 1999, Smit \& Skinner 2002). Adaptive capacity is the ability of a system or society to modify its characteristics or behavior so as to cope better with changes brought about by external conditions such as climate change (including climate variability and extremes). These responses enable affected communities to moderate potential damage and take advantage of opportunities presented by these external shocks (IPCC 2001). 
Research on interactions of climate change and agriculture has evolved from a "top down" to a "bottom-up" approach. The top-down approach focuses on predicting impacts of climate change scenarios, and identifies potential adaptation practices to these scenarios. The bottom-up approach, on the other hand, focuses on existing biophysical and socio-economic environments in assessing the vulnerability of those affected by climate change. In this later approach, adaptation strategies are processes involving several aspects including the policy environments, producers' perceptions and other elements of decision making (Bryant et al. 2000, Wall \& Smit 2005, Belliveau et al. 2006).

The present paper adopts the bottom-up approach to investigate factors affecting the choice of adaptation strategies (practices and technologies) to climate change at farm level. The study surveyed farming households in the arid Limpopo river basin in South Africa to assess farmers' perceptions regarding long-term changes in local climate, and their primary adaptation responses and factors constraining their capacity to adapt. The paper, therefore, aims to generate important policy information on how to enhance adaptive capacities of rural households in stressed environments like the Limpopo basin.

The next section describes the data used in the study, and section 3 discusses climate adaptation responses of farmers in the Limpopo basin. Section 4 presents the analytical framework, while section 5 discusses the selection of variables to include in the analysis and hypotheses to be tested. Results are presented and discussed in section 6, and conclusions and policy implications of the study are given in the final section.

\section{SOURCES AND METHODS OF DATA COLLECTION}

The household level data used in this study was obtained from a project entitled Food and Water Security under Global Change: Developing Adaptive Capacity with a Focus on Rural Africa, funded by Germany's Advisory Service on Agricultural Research for Development. Under the project, a survey was carried out by the Centre for Environmental Economics and Policy in Africa (CEEPA), University of Pretoria, in collaboration with the International Food Policy Research Institute (IFPRI) to analyze the potential impact of climate variability and climate change on household vulnerability and farm production. The survey was carried out between August and November 2005, covering the April/May 2004 to April/May 2005 agricultural season. In total, 794 surveys were completed in 19 districts from four provinces in South Africa (Limpopo, North West, Mpumalanga and Gauteng). Farmers were carefully selected with the assistance of producers' associations and the National Department of Agriculture. While the survey collected data on a wide range of attributes of the studied community and region, this study used the sections of the survey on perceptions of climate change, adaptations made by 
farmers and barriers to adaptation. Open-ended questions were used to ask farmers whether they had noticed long-term changes in mean temperature, mean rainfall and the direction of the change. Farmers were also asked about their adaptation responses and constraints faced.

\section{ADAPTATION STRATEGIES OF FARMERS IN THE LIMPOPO BASIN OF SOUTH AFRICA}

A number of studies note a disconnection between farmers' perceptions of climate change and actual adaptation responses (Smit et al. 1996, Brklacich et al. 1997, Granjon 1999). This study gives similar findings. Our study indicates that although a large number of interviewed farmers indicated they noticed long term changes in mean temperature and precipitation levels, about two-thirds failed to take remedial action. The majority of the farmers surveyed perceived an increase in temperature and a decreasing trend in rainfall ( 89 per cent and 81 per cent, respectively) over the past 20 years. Table 1 describes farmers' adaptation strategies in the Limpopo river basin. Common responses of those farmers who managed to adapt, included planting different crops, changing crop varieties, changing planting dates, increasing use of irrigation, changing area of land grazed or cultivated and supplementing livestock feed. While adopting a new crop variety was one of the main strategies used to adapt to increasing temperature, building water-harvesting schemes was a popular strategy for coping with decreased precipitation. Adaptation measures taken by South African farmers are similar to those reported in other studies in the climate change adaptation literature (Bradshaw et al. 2004, Maddison 2006, Nhemachena \& Hassan 2007, Deressa et al. 2009).

The reported barriers to adaptation are shown in table 2. Farmers cited a number of barriers to adaptation including poverty, lack of access to credit, water and markets, and low savings. Insecure property rights were also cited as an important barrier to adaptation. A few farmers also reported lack of information and knowledge of appropriate measures as barriers to adaptation. 
Glwadys Aymone Gbetibouo, Rashid M. Hassan and Claudia Ringler

Table 1: Farmers' adaptation strategies in Limpopo River Basin

\begin{tabular}{|c|c|c|c|c|c|}
\hline Variable & Total Basin & Limpopo & North West & Gauteng & Mpumalanga \\
\hline \multicolumn{6}{|c|}{ Adaptation to long-term changes in temperature (\% respondents) } \\
\hline Change crop variety & 3.03 & 1.21 & 3.92 & 2.27 & 6.57 \\
\hline Increasing irrigation & 3.96 & 3.38 & 1.96 & 6.82 & 5.56 \\
\hline Plant different crops & 6.86 & 9.66 & 3.62 & & 4.04 \\
\hline Change planting date & 3.69 & 3.62 & 0.98 & 6.82 & 4.55 \\
\hline $\begin{array}{l}\text { Change amount of } \\
\text { land }\end{array}$ & 3.43 & 4.11 & 1.96 & 2.27 & 3.03 \\
\hline $\begin{array}{l}\text { Livestock feed } \\
\text { supplements }\end{array}$ & 3.69 & 3.62 & 5.88 & 4.55 & 2.53 \\
\hline $\begin{array}{l}\text { Crop diversification/ } \\
\text { mixing }\end{array}$ & 0.53 & 0.97 & & & \\
\hline Other & 5.01 & 4.83 & 2.94 & 6.82 & 6.06 \\
\hline No adaptation & 69.39 & 67.87 & 78.43 & 70.45 & 67.68 \\
\hline \multicolumn{6}{|c|}{ Adaptation to long-term changes in rainfall (\% respondents) } \\
\hline Change crop variety & 0.66 & 0.72 & & & 1.01 \\
\hline Increasing irrigation & 7.75 & 4.82 & 13.99 & 4.55 & 11.56 \\
\hline Plant different crops & 4.99 & 6.75 & 2.91 & 2.27 & 3.02 \\
\hline Change planting date & 4.73 & 3.13 & 3.88 & 9.09 & 7.54 \\
\hline $\begin{array}{l}\text { Change amount of } \\
\text { land }\end{array}$ & 2.76 & 4.43 & & & 1.51 \\
\hline $\begin{array}{l}\text { Livestock feed } \\
\text { supplements }\end{array}$ & 2.23 & 2.41 & 3.88 & 2.27 & 1.01 \\
\hline $\begin{array}{l}\text { Water-harvesting } \\
\text { scheme }\end{array}$ & 3.81 & 3.61 & 1.94 & 4.55 & 5.03 \\
\hline Other & 5.12 & 4.34 & 4.85 & 4.55 & 7.04 \\
\hline No adaptation & 67.94 & 69.88 & 68.06 & 72.73 & 62.31 \\
\hline
\end{tabular}


Table 2: Barriers to adaptation in the Limpopo River Basin (\% of the respondents)

\begin{tabular}{|c|c|c|c|c|c|c|c|c|}
\hline & 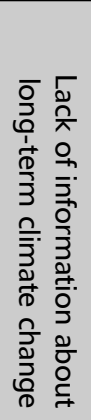 & 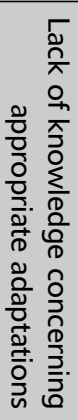 & 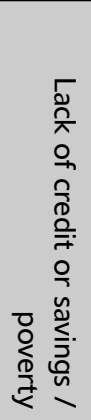 & 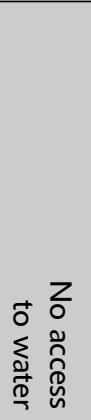 & 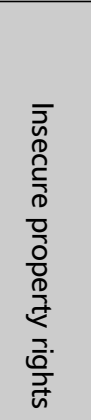 & 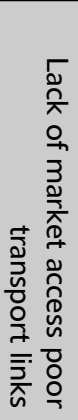 & 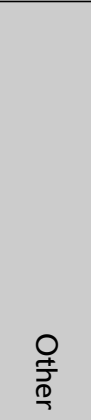 & 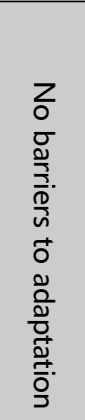 \\
\hline Total Basin & 6.03 & 1.95 & 53.9 & 20.75 & 9.57 & 6.21 & 10.99 & 0.78 \\
\hline Limpopo & 4.32 & 2.65 & 24.24 & 32.58 & 14.27 & 10.3 & 7.97 & 8.31 \\
\hline North West & 10.47 & 0.00 & 54.65 & 3.49 & 3.49 & 1.16 & 9.3 & 22.09 \\
\hline Gauteng & 0.00 & 0.00 & 32 & 12 & 0.00 & 4 & 20 & 10 \\
\hline Mpumalanga & 8.56 & 1.98 & 48.04 & 8.56 & 5.92 & 1.32 & 13.10 & 23.03 \\
\hline
\end{tabular}

\section{$4 \quad$ ANALYTICAL FRAMEWORK OF THE STUDY}

The decision of whether or not to use any adaptation option could fall under the general framework of utility and profit maximization. Consider a rational farmer who seeks to maximize the present value of expected benefits of production over a specified time horizon, and must choose among a set of $J$ adaptation options. The farmer $i$ decides to use $j$ adaptation option if the perceived benefit from option $j$ is greater than the utility from other options (say, $k$ ) depicted as

$$
U_{i j}\left(\beta_{j}^{\prime} X_{i}+\varepsilon_{j}\right)>U_{i k}\left(\beta_{k}^{\prime} X_{i}+\varepsilon_{k}\right), k \neq j,
$$

Where $\mathrm{U}_{\mathrm{ij}}$ and $\mathrm{U}_{\mathrm{ik}}$ are the perceived utility by farmer $i$ of adaptation options $j$ and $k$, respectively; $\mathrm{X}_{\mathrm{i}}$ is a vector of explanatory variables that influence the choice of the adaptation option; $\beta_{\mathrm{j}}$ and $\beta_{\mathrm{k}}$ are parameters to be estimated; and $\varepsilon_{\mathrm{j}}$ and $\varepsilon_{\mathrm{k}}$ are error terms.

Under the revealed preference assumption that the farmer practices an adaptation option that generates net benefits, and does not practice an adaptation option otherwise, we can relate the observable discrete choice of practice to the unobservable (latent) continuous net benefit variable as $\mathrm{Y}_{\mathrm{ij}}=1$ if $U_{i j}>0$ and $\mathrm{Y}_{\mathrm{ij}}$ $=0$ if $U_{i j}<0$. In this formulation, $\mathrm{Y}$ is a dichotomous dependent variable, taking the value of 1 when the farmer chooses an adaptation option in question and 0 otherwise. 
Accordingly, the probability that farmer $i$ will choose adaptation option $j$ among the set of adaptation options could be defined as follows:

$$
\begin{aligned}
\mathrm{P}(Y=1 / X) & =P\left(U_{i j}>U_{i k} / X\right) \\
& =P\left(\beta_{k}^{\prime} X_{i}+\varepsilon_{j}-\beta_{k}^{\prime} X_{i}-\varepsilon_{k}>0 / X\right) \\
& =P\left(\left(\beta_{j}^{\prime}-\beta_{k}^{\prime}\right) X_{i}+\varepsilon_{j}-\varepsilon_{k}>0 / X\right) \\
& =P\left(\beta^{*} X_{i}+\varepsilon^{*}>0 / X\right)=F\left(\beta^{*} X_{i}\right),
\end{aligned}
$$

Where $\varepsilon^{*}$ is a random disturbance term, $\beta^{*}$ is a vector of unknown parameters that can be interpreted as the net influence of the vector of explanatory variables influencing adaptation, and $\mathrm{F}\left(\beta^{*} \mathrm{X}_{\mathrm{i}}\right)$ is the cumulative distribution of $\varepsilon^{*}$ evaluated at $\beta^{*} X_{\mathrm{i}}$.

Given that we investigate several adaptation choices, the multinomial logit (MNL) model is employed to analyze climate change adaptation behaviour of farmers. Thus, the probability that household $i$ with characteristics $\mathrm{X}$ chooses adaptation option $\mathrm{j}$ is specified as follows:

$$
\operatorname{Pij}=\operatorname{prob}(\mathrm{Y}=1)=\frac{e^{x^{\prime \beta}}}{1+\sum_{j=1}^{j} e^{x^{\prime \beta}}}, \mathrm{j}=1 \ldots \mathrm{j},
$$

Where $\beta$ is a vector of parameters that satisfy $\ln \left(\mathrm{P}_{\mathrm{ij}} / \mathrm{P}_{\mathrm{i} \mathrm{k}}\right)=\mathrm{X}^{\prime}\left(\beta_{\mathrm{j}}-\beta_{\mathrm{k}}\right)($ Greene 2003). Unbiased and consistent parameter estimates of the MNL model in Equation (3) require the assumption of independence of irrelevant alternatives (IIA) to hold (Greene 2003). Specifically, the IIA assumption requires that the likelihood of a household's using a certain adaptation measure needs to be independent of alternative adaptation measures used by the same household. Thus, the IIA assumption implies independent and homoscedastic disturbance terms of the adaptation model in Equation (1). The validity of the IIA assumption could be tested using the Hausman's specification, which is based on the fact that if a choice set is irrelevant, eliminating a choice or choice sets from the model altogether will not change parameter estimates systematically (Hausman 1978).

Differentiating Equation (3) with respect to each explanatory variable provides measures of the marginal effects of these variables:

$$
\frac{\partial P_{j}}{\partial x_{k}}=P_{j}\left(\beta_{j k}-\sum_{j=1}^{j-1} P_{j} \beta_{j k}\right)
$$




\section{CHOICE OF MODEL VARIABLES AND HYPOTHESES TO BE TESTED}

Based on the above information about adaptation choices in table 1, the choice sets considered in the adaptation model include seven variables: (1) Portfolio diversification representing an aggregate of choices undertaken for the purpose of risk spreading. It includes changing crop variety, planting of different crops, and mixing crop and livestock systems. (2) Irrigation denoting an aggregate of choices in using water for the purpose of increasing productivity and coping with rainwater shortages, including increasing area under irrigation and use of water-harvesting practices. (3) Changing planting date. (4) Changing land area under cultivation. (5) Use of livestock feed supplements. (6) Other adaptation methods. ${ }^{4}$ (7) No adaptation as the reference/control choice. Table 3 provides a brief description of each explanatory variable and expected direction of its influence on adaptation choices.

Explanatory variables were chosen based on data availability and the literature. A review of literature on adoption of new technologies and adaptation studies suggests the importance of a number of household and farm characteristics as well as institutional factors and other determinants in influencing farmers' adaptation choices.

Table 3 provides a brief description of each explanatory variable and expected direction of its influence on adaptation choices.

1. Household characteristics. Adesina and Forson (1995 cited in Teklewold et al. 2006) did not find agreement in the adoption literature on the effect of farmer's age, which was generally location- or technology-specific. On the other hand, higher levels of education of farmers often were found to increase the probability of adopting new technologies (Daberkow \& McBride 2003, Adesina \& Forson 1995). Education is expected to increase one's ability to receive, decode, and understand information relevant to making innovative decisions (Wozniak 1984). Gender of the household head was also found to influence adoption decisions. A number of studies in Africa have shown that women have lesser access to critical resources (land, cash and labour), which often undermines their ability to carry out labour-intensive agricultural innovations (De Groote \& Coulibaly 1998, Quisumbing et al. 1995). However, a study by Nhemachena and Hassan (2007) found that femaleheaded households are more likely to take up climate change adaptation methods. Wealth is believed to reflect past achievements of households and their ability to bear risks. Thus, households with higher income and greater assets are in a better position to adopt new farming technologies (Shiferaw \& Holden 1998). Farming experience is hypothesized to increase the probability 
Glwadys Aymone Gbetibouo, Rashid M. Hassan and Claudia Ringler

Table 3: Variables hypothesized to affect adaptation decisions of farmers in the Limpopo River Basin

\begin{tabular}{|c|c|c|c|}
\hline Variable name & Description & Unit & Expected sign \\
\hline \multicolumn{4}{|c|}{ Household characteristics } \\
\hline Age & $\begin{array}{l}\text { Age of the head of } \\
\text { the farm household }\end{array}$ & Years & $\begin{array}{l}\text { Cannot be signed a } \\
\text { priori (+ or }- \text { ) }\end{array}$ \\
\hline Education & $\begin{array}{l}\text { Number of years } \\
\text { of formal schooling } \\
\text { attainded by } \\
\text { the head of the } \\
\text { household }\end{array}$ & Years & Positive \\
\hline Gender & $\begin{array}{l}\text { Gender of the } \\
\text { head of the farm } \\
\text { household }\end{array}$ & $\begin{array}{l}1=\text { male, } 0= \\
\text { female }\end{array}$ & $\begin{array}{l}\text { Cannot be signed a } \\
\text { priori (+ or }- \text { ) }\end{array}$ \\
\hline Household size & $\begin{array}{l}\text { Number of family } \\
\text { members of a } \\
\text { household }\end{array}$ & Number & $\begin{array}{l}\text { Cannot be signed a } \\
\text { priori (+ or }- \text { ) }\end{array}$ \\
\hline Farming experience & $\begin{array}{l}\text { Number of years of } \\
\text { farming experience } \\
\text { for the household } \\
\text { head }\end{array}$ & Years & Positive \\
\hline Wealth & $\begin{array}{l}\text { An index }{ }^{5} \text { was } \\
\text { conducted } \\
\text { using household } \\
\text { ownership of seven } \\
\text { household assets: } \\
\text { television, radio, } \\
\text { flushing toilet, cell } \\
\text { phone, brick house, } \\
\text { refrigerator and car. }\end{array}$ & Number & Postive \\
\hline \multicolumn{4}{|l|}{ Farm characteristics } \\
\hline Farm size & $\begin{array}{l}\text { Determine if the } \\
\text { farm is large scale or } \\
\text { small scale }\end{array}$ & $\begin{array}{l}1=\text { large scale, } 0= \\
\text { smale scale }\end{array}$ & Positive \\
\hline Soil fertility & $\begin{array}{l}\text { Farmer's own } \\
\text { perception of the } \\
\text { fertility level of } \\
\text { his land. Three } \\
\text { dummies: infertile, } \\
\text { fertile and highly } \\
\text { fertile. }\end{array}$ & 0 or 1 & Positive \\
\hline
\end{tabular}


Modelling farmers' adaptation strategies for climate change and variability ...

\begin{tabular}{|c|c|c|c|}
\hline \multicolumn{4}{|l|}{ Institutional factors } \\
\hline Extension & $\begin{array}{l}\text { If household has } \\
\text { access to extension } \\
\text { services }\end{array}$ & $1=$ yes, $0=$ no & Positive \\
\hline Climate information & $\begin{array}{l}\text { If household gets } \\
\text { information about } \\
\text { weather, climate } \\
\text { from any source } \\
\text { (extension officers, } \\
\text { TV, radio, etc.) }\end{array}$ & $1=$ yes, $2=$ no & Positive \\
\hline Credit & $\begin{array}{l}\text { If household has } \\
\text { access to credit from } \\
\text { any source }\end{array}$ & $1=$ yes, $0=$ no & Positive \\
\hline $\begin{array}{l}\text { Off-farm } \\
\text { employment }\end{array}$ & $\begin{array}{l}\text { Income from off- } \\
\text { farm activities during } \\
\text { the survey year }\end{array}$ & & $\begin{array}{l}\text { Cannot be signed a } \\
\text { priori (+ or }- \text { ) }\end{array}$ \\
\hline Tenure & $\begin{array}{l}\text { If land use is owned } \\
\text { or rented/share- } \\
\text { cropped, etc. }\end{array}$ & $\begin{array}{l}1 \text { = owned } \\
0=\text { otherwise }\end{array}$ & Positive \\
\hline \multicolumn{4}{|l|}{ Other factors } \\
\hline Temperature & $\begin{array}{l}\text { Average temperature } \\
\text { between } 1960 \text { and } \\
2003\end{array}$ & degree Celsius & Positive \\
\hline Rainfall & $\begin{array}{l}\text { Average rainfall } \\
\text { between } 1960 \text { and } \\
2003\end{array}$ & $\mathrm{~mm}$ & Negative \\
\hline Latitude & & degree & \\
\hline Longitude & & degree & \\
\hline Limpopo & $\begin{array}{l}\text { If household farm is } \\
\text { in Limpopo province }\end{array}$ & $1=$ yes, $0=$ no & $\begin{array}{l}\text { Cannot be signed a } \\
\text { priori (+ or -) }\end{array}$ \\
\hline
\end{tabular}


of uptake of all adaptation options, because experienced farmers have better knowledge and information on changes in climatic conditions, and crop and livestock management practices (Nhemachena \& Hassan 2007). The influence of household size on the decision to adapt has been ambiguous. Household size as a proxy to labour availability may influence adoption of a new technology positively as its availability reduces labour constraints (Teklewold et al. 2006). However, the study of Tizale (2007) suggests that there is a possibility that households with many family members may be forced to divert part of the labour force to off-farm activities in an attempt to earn income to ease the consumption pressure imposed by a large family size.

2. Farm characteristics. The literature suggests that adoption of an innovation tends to take place earlier on larger farms than on smaller ones. Daberkow and McBride (2003) show that, given the uncertainty and the fixed transaction and information costs associated with innovation, there may be a critical lower limit on farm size that prevents smaller farms from adapting. As these costs increase, the critical size also increases. It follows that innovations with large fixed transaction and/or information costs are less likely to be adopted by smaller farms. Fertility of the farm land is also considered an important element, as farmers' perceptions that their lands are infertile may be a first step in the adaptation process. They may, therefore, be more likely to adopt any adaptation techniques that will help improve their productivity.

3. Institutional factors. In the world of less-than-perfect information, the introduction of new technologies creates a demand for information useful in deciding on adopting new technologies (Wozniak 1984). Of the many sources of information available to farmers, agricultural extension is the most important for analyzing the adoption decision. Based on the innovationdiffusion literature, it is hypothesized that access to extension services is positively related to adoption of new technologies by exposing farmers to new information and technical skills (Adesina \& Forson 1995). Also, in the specific case of climate change adaptation, access to climate information may increase the likelihood of uptake of adaptation measures.

Access to credit is another variable that has received attention, which was commonly found to have a positive effect on adaptation (Caviglia-Harris 2002, Saín \& Barreto 1996, Napier 1991, Hansen et al. 1987). Any fixed investment requires the use of owned or borrowed capital. Hence, the adoption of a technology requires a large initial investment, which may be hampered by lack of borrowing capacity (El-Osta \& Morehart 1999).

The occupation of the farmer is an indication of the total amount of time available for farming activities. Off-farm employment may present a constraint to adoption of technology, because it competes for on-farm work (McNamara 
et al. 1991). Similarly, land tenure can contribute to adaptation, because landowners tend to adopt new technologies more frequently than tenants, an argument that has justified numerous efforts to reduce tenure insecurity (Lutz et al. 1994, Shultz et al. 1997). Land ownership is widely believed to encourage the adoption of technologies linked to land such as irrigation equipment or drainage structures. Land ownership is likely to influence adoption if the innovation requires investments tied to land.

4. Other factors. Local climatic and agro-ecological conditions are expected to influence the decision to adapt. We, therefore, included district level climate variables (temperature and rainfall). Also, to take into account spatial autocorrelation and neighbourhood effects, we include location attributes (latitude and longitude coordinates) of each household. A dummy variable is also included to control for the fixed province effects, reflecting any specific institutional arrangements with bearing on the ability of farmers to adapt to climate change in a particular province.

\section{DISCUSSION OF THE EMPIRICAL RESULTS}

The above specified MNL adaptation model was tested for the IIA assumption using the Hausman specification test. The test failed to reject the null hypothesis of independence of the included choices, suggesting there is no evidence against the current specification of the adaptation model giving a $\chi^{2}=-0.375$ with $P$ value of 0.9311 . Therefore, the application of the MNL specification to the data set for modelling climate change adaptation behaviour of farmers is justified.

Tables 4 and 5 present the estimated coefficients and the marginal effects, respectively. The likelihood ratio statistics $\left(\chi^{2}=291.07\right)$ are highly significant at one percent, suggesting a strong explanatory power of the model. It is important to note that the estimated coefficients should be compared with the base category of not adopting any of the adaptation choices. There is a 70 percent probability that farmers will not adapt to climate change. The results show that a large household will be more willing to choose the "Other" category as an adaptation option, which includes adaptations such as use of soil conservation techniques and chemical treatments that are labour-intensive, especially in small-scale farming. Experienced farmers have an increased likelihood of using portfolio diversification, changing planting dates, and changing the amount of land under production. These results confirm the findings of Nhemachena and Hassan (2007) in a similar study of adaptation in the Southern Africa region. Experienced farmers have high skills in farming techniques and management, and are able to spread risk when facing climate variability by exploiting strategic complementarities between activities such as crop-livestock integration. Wealthier households were found to be more willing to adapt by changing their planting dates. Surprisingly, the results 
suggested that education level and gender did not have a significant impact on the probability of choosing any particular adaptation technique.

The coefficient on farm size is significant and positively correlated with the probability of choosing irrigation as an adaptation measure. Indeed, large-scale farmers are more likely to adopt irrigation as they have more capital and resources to invest in irrigation technologies. The perception of having highly fertile soil increases the probability that farmers will change their amount of land under cultivation.

Having access to extension increases the probability of choosing portfolio diversification by four percent. It appears, therefore, that extension messages in the study area emphasized risk spreading and farm-level risk management. The implementation of the land reform has increased the number of new, emerging farmers who did not have the skills and information gathered by experienced farmers; therefore, extension is paramount in South Africa.

As expected, access to credit increases the likelihood of adaptation. Poverty or lack of financial resources is one of the main constraints on adjustment to climate change. In a study on Tanzania, O'Brien et al. (2000) report that despite numerous adaptation options that farmers are aware of and willing to apply, the lack of sufficient financial resources to purchase the necessary inputs and other associated equipment (e.g., purchasing seeds, acquiring transportation, hiring temporary workers) is one of the key constraints to adaptation. In our study, 60 percent of the respondents who did not adapt cited lack of financial resources as the main constraint to adaptation. The results show that access to credit increases the likelihood that farmers will take up portfolio diversification and buy feed supplements for their livestock.

Having secure property rights increases the probability of farmers to adapt by nine percent. With proper property rights, farmers may be able to change their amount of land under cultivation to adjust to new climatic conditions. While offfarm employment may present a constraint to adaptation because it competes for on-farm work (McNamara et al. 1991), the empirical results suggest that off-farm activities increase the likelihood of buying feed supplements for the livestock. This suggests that expanding smallholder farmers' access to off-farm income and employment opportunities increases the probability that they will invest in farming activities.

Households living in regions with high temperatures have an increased likelihood of adapting. These households are more likely to choose the following adaptation options: (1) portfolio diversification, such as changing their types of crops (e.g., from maize to sorghum, a more heat-tolerant crop); (2) intensify irrigation; and (3) change planting dates. A decrease in rainfall is likely to push farmers to delay planting. 
Modelling farmers' adaptation strategies for climate change and variability ...

Table 4: Coefficient estimates of the multinomial logit adaptation model, Limpopo River Basin

\begin{tabular}{|c|c|c|c|c|c|c|}
\hline & $\begin{array}{c}\text { Portfolio } \\
\text { diversifi- } \\
\text { cation }\end{array}$ & Irrigation & $\begin{array}{c}\text { Changed } \\
\text { planting } \\
\text { dates }\end{array}$ & $\begin{array}{l}\text { Changed } \\
\text { the amount } \\
\text { of land }\end{array}$ & $\begin{array}{l}\text { Livestock } \\
\text { feed sup- } \\
\text { plements }\end{array}$ & Other \\
\hline Education & $\begin{array}{c}-0.0256 \\
(0.45)\end{array}$ & $\begin{array}{l}0.015 \\
(0.56)\end{array}$ & $\begin{array}{c}-0.0072 \\
(0.84)\end{array}$ & $\begin{array}{l}0.0239 \\
(0.54)\end{array}$ & $\begin{array}{c}-0.02606 \\
(0.63)\end{array}$ & $\begin{array}{c}0.0274 \\
(0.51)\end{array}$ \\
\hline Gender & $\begin{array}{c}-0.0381 \\
(0.90)\end{array}$ & $\begin{array}{l}0.390 \\
(0.24)\end{array}$ & $\begin{array}{l}0.4163 \\
(0.39)\end{array}$ & $\begin{array}{c}-0.2365 \\
(0.61)\end{array}$ & $\begin{array}{c}0.5869 \\
(0.41)\end{array}$ & $\begin{array}{c}-0.0687 \\
(0.89)\end{array}$ \\
\hline Household size & $\begin{array}{c}-0.0256 \\
(0.62)\end{array}$ & $\begin{array}{l}0.045 \\
(0.34)\end{array}$ & $\begin{array}{c}-0.0065 \\
(0.92)\end{array}$ & $\begin{array}{l}0.0235 \\
(0.80)\end{array}$ & $\begin{array}{c}-0.1032 \\
(0.23)\end{array}$ & $\begin{array}{l}-0.1206 \\
(0.09)^{*}\end{array}$ \\
\hline Farming experience & $\begin{array}{c}0.0283 \\
(0.01)^{\star \star \star}\end{array}$ & $\begin{array}{l}0.011 \\
(0.36)\end{array}$ & $\begin{array}{c}0.0362 \\
(0.01)^{\star \star \star}\end{array}$ & $\begin{array}{c}0.0478 \\
(0.00)^{\star * \star}\end{array}$ & $\begin{array}{c}-0.0159 \\
(0.55)\end{array}$ & $\begin{array}{l}0.0015 \\
(0.92)\end{array}$ \\
\hline Wealth & $\begin{array}{c}-0.0439 \\
(0.66)\end{array}$ & $\begin{array}{c}0.152 \\
(0.09)^{\star}\end{array}$ & $\begin{array}{c}0.7200 \\
(0.00)^{\star \star \star *}\end{array}$ & $\begin{array}{l}0.3255 \\
(0.07)^{\star}\end{array}$ & $\begin{array}{l}0.1524 \\
(0.32)\end{array}$ & $\begin{array}{l}0.1223 \\
(0.43)\end{array}$ \\
\hline Farm size & $\begin{array}{l}0.7903 \\
(0.09)^{*}\end{array}$ & $\begin{array}{c}0.994 \\
(0.03)^{\star *}\end{array}$ & $\begin{array}{c}0.3967 \\
(0.65)\end{array}$ & $\begin{array}{l}0.8507 \\
(0.26)\end{array}$ & $\begin{array}{l}0.2231 \\
(0.86)\end{array}$ & $\begin{array}{l}0.3850 \\
(0.58)\end{array}$ \\
\hline Highly fertile soil & $\begin{array}{l}0.4521 \\
(0.10)^{\star}\end{array}$ & $\begin{array}{l}0.335 \\
(0.29)\end{array}$ & $\begin{array}{l}-0.1061 \\
(0.823)\end{array}$ & $\begin{array}{c}1.0011 \\
(0.05)^{\star \star}\end{array}$ & $\begin{array}{c}0.7963 \\
(0.19)\end{array}$ & $\begin{array}{c}-0.3737 \\
(0.50)\end{array}$ \\
\hline Infertile soil & $\begin{array}{c}-0.4928 \\
(0.44)\end{array}$ & $\begin{array}{l}-0.120 \\
(0.81)\end{array}$ & $\begin{array}{l}0.2631 \\
(0.658)\end{array}$ & $\begin{array}{l}1.0477 \\
(0.14)\end{array}$ & $\begin{array}{c}-0.3601 \\
(0.71)\end{array}$ & $\begin{array}{l}0.9341 \\
(0.09)^{*}\end{array}$ \\
\hline Extension & $\begin{array}{l}0.5876 \\
(0.09)^{\star}\end{array}$ & $\begin{array}{l}0.016 \\
(0.95)\end{array}$ & $\begin{array}{l}0.4915 \\
(0.27)\end{array}$ & $\begin{array}{l}0.5658 \\
(0.22)\end{array}$ & $\begin{array}{c}0.2494 \\
(0.62)\end{array}$ & $\begin{array}{l}0.0001 \\
(0.99)\end{array}$ \\
\hline Climate information & $\begin{array}{c}-0.3225 \\
(0.33)\end{array}$ & $\begin{array}{l}-0.009 \\
(0.97)\end{array}$ & $\begin{array}{c}-0.3602 \\
(0.42)\end{array}$ & $\begin{array}{l}0.2471 \\
(0.61)\end{array}$ & $\begin{array}{c}-0.1404 \\
(0.80)\end{array}$ & $\begin{array}{l}0.4426 \\
(0.29)\end{array}$ \\
\hline Credit & $\begin{array}{l}0.4903 \\
(0.08)^{*}\end{array}$ & $\begin{array}{l}0.348 \\
(0.26)\end{array}$ & $\begin{array}{l}0.0860 \\
(0.87)\end{array}$ & $\begin{array}{c}-0.9608 \\
(0.13)\end{array}$ & $\begin{array}{c}1.2228 \\
(0.02)^{\star \star}\end{array}$ & $\begin{array}{l}0.5648 \\
(0.22)\end{array}$ \\
\hline Off-farm employment & $\begin{array}{c}0.4091 \\
(0.19)\end{array}$ & $\begin{array}{l}0.050 \\
(0.87)\end{array}$ & $\begin{array}{l}0.1044 \\
(0.80)\end{array}$ & $\begin{array}{c}-0.7191 \\
(0.31)\end{array}$ & $\begin{array}{c}2.1167 \\
(0.00)^{\star \star \star}\end{array}$ & $\begin{array}{l}0.2936 \\
(0.50)\end{array}$ \\
\hline Tenure & $\begin{array}{c}0.2672 \\
(0.36)\end{array}$ & $\begin{array}{l}0.304 \\
(0.31)\end{array}$ & $\begin{array}{c}0.4309 \\
(0.28)\end{array}$ & $\begin{array}{c}1.1490 \\
(0.02)^{\star \star}\end{array}$ & $\begin{array}{c}-0.3775 \\
(0.49)\end{array}$ & $\begin{array}{c}1.3012 \\
(0.00)^{\star \star \star}\end{array}$ \\
\hline Latitude & $\begin{array}{c}0.4806 \\
(0.05)^{\star *}\end{array}$ & $\begin{array}{l}-0.142 \\
(0.25)\end{array}$ & $\begin{array}{c}-0.2132 \\
(0.17)\end{array}$ & $\begin{array}{l}0.7003 \\
(0.09)^{\star}\end{array}$ & $\begin{array}{c}-0.3234 \\
(0.07)^{\star}\end{array}$ & $\begin{array}{c}0.0809 \\
(0.58)\end{array}$ \\
\hline Longitude & $\begin{array}{c}-0.1496 \\
(0.45)\end{array}$ & $\begin{array}{l}-0.016 \\
(0.92)\end{array}$ & $\begin{array}{c}0.5093 \\
(0.03)^{\star \star}\end{array}$ & $\begin{array}{c}0.5458 \\
(0.23)\end{array}$ & $\begin{array}{c}-0.4082 \\
(0.09)^{\star}\end{array}$ & $\begin{array}{c}-0.1312 \\
(0.54)\end{array}$ \\
\hline Rainfall & $\begin{array}{c}0.0062 \\
(0.12)\end{array}$ & $\begin{array}{l}0.004 \\
(0.13)\end{array}$ & $\begin{array}{l}-0.0071 \\
(0.04)^{\star \star}\end{array}$ & $\begin{array}{l}0.0079 \\
(0.269)\end{array}$ & $\begin{array}{l}0.0001 \\
(0.97)\end{array}$ & $\begin{array}{c}-0.0007 \\
(0.86)\end{array}$ \\
\hline Temperature & $\begin{array}{c}0.1851 \\
(0.02)^{\star \star}\end{array}$ & $\begin{array}{c}0.144 \\
(0.08)^{\star}\end{array}$ & $\begin{array}{l}-0.2957 \\
(0.00)^{\star \star \star}\end{array}$ & $\begin{array}{l}0.0783 \\
(0.53)\end{array}$ & $\begin{array}{c}0.0855 \\
(0.60)\end{array}$ & $\begin{array}{l}0.2502 \\
(0.03)^{\star *}\end{array}$ \\
\hline Intercept & $\begin{array}{c}6.1086 \\
(0.49) \\
\end{array}$ & $\begin{array}{l}-11.102 \\
(0.05)^{\star \star}\end{array}$ & $\begin{array}{c}-14.0650 \\
(0.09)^{\star}\end{array}$ & $\begin{array}{c}-10.6187 \\
(0.53)\end{array}$ & $\begin{array}{c}-2.6090 \\
(0.75) \\
\end{array}$ & $\begin{array}{c}-2.3139 \\
(0.74)\end{array}$ \\
\hline Base category & \multicolumn{6}{|c|}{ No Adaptation } \\
\hline No. observations & \multicolumn{6}{|c|}{591} \\
\hline LR chi-square (90) & \multicolumn{6}{|c|}{$291.07^{* \star *}$} \\
\hline Log pseudo likelihood & \multicolumn{6}{|c|}{-676.2506} \\
\hline Pseudo R-Square & \multicolumn{6}{|c|}{0.1320} \\
\hline
\end{tabular}

Notes: ${ }^{* * *}$ significant at $1 \%$ probability level, ${ }^{* *}$ significant at $5 \%$ probability level, * significant at $10 \%$ probability level 
Table 5: Estimates of the marginal effects of the MNL adaptation model, Limpopo River Basin

\begin{tabular}{|c|c|c|c|c|c|c|c|}
\hline & $\begin{array}{l}\text { Portfolio } \\
\text { diversifi- } \\
\text { cation }\end{array}$ & Irrigation & $\begin{array}{l}\text { Changed } \\
\text { planting } \\
\text { dates }\end{array}$ & $\begin{array}{l}\text { Changed } \\
\text { amount } \\
\text { of land }\end{array}$ & $\begin{array}{l}\text { Livestock } \\
\text { feed sup- } \\
\text { plements }\end{array}$ & Other & $\begin{array}{c}\text { No } \\
\text { Adapta- } \\
\text { tion }\end{array}$ \\
\hline Education & $\begin{array}{c}-0.0023 \\
(0.39)\end{array}$ & $\begin{array}{l}0.0019 \\
(0.50)\end{array}$ & $\begin{array}{c}-0.0003 \\
(0.82)\end{array}$ & $\begin{array}{c}0.0003 \\
(0.56)\end{array}$ & $\begin{array}{c}-0.0003 \\
(0.62)\end{array}$ & $\begin{array}{c}0.0009 \\
(0.49)\end{array}$ & $\begin{array}{c}-0.0003 \\
(0.94)\end{array}$ \\
\hline Gender & $\begin{array}{c}-0.0084 \\
(0.75)\end{array}$ & $\begin{array}{l}0.0388 \\
(0.22)\end{array}$ & $\begin{array}{c}0.0115 \\
(0.38)\end{array}$ & $\begin{array}{c}-0.0034 \\
(0.54)\end{array}$ & $\begin{array}{l}0.0046 \\
(0.41)\end{array}$ & $\begin{array}{c}-0.0044 \\
(0.8)\end{array}$ & $\begin{array}{c}-0.0387 \\
(0.37)\end{array}$ \\
\hline Household size & $\begin{array}{c}-0.0021 \\
(0.60)\end{array}$ & $\begin{array}{l}0.0058 \\
(0.25)\end{array}$ & $\begin{array}{c}-0.0002 \\
(0.94)\end{array}$ & $\begin{array}{c}0.0003 \\
(0.79)\end{array}$ & $\begin{array}{c}-0.0010 \\
(0.25)\end{array}$ & $\begin{array}{c}-0.0041 \\
(0.09)^{\star}\end{array}$ & $\begin{array}{c}0.0013 \\
(0.85)\end{array}$ \\
\hline Farming experience & $\begin{array}{c}0.0020 \\
(0.01)^{\star * *}\end{array}$ & $\begin{array}{c}0.0007 \\
(0.59)\end{array}$ & $\begin{array}{c}0.0011 \\
(0.03)^{\star \star}\end{array}$ & $\begin{array}{l}0.0005 \\
(0.09)^{*}\end{array}$ & $\begin{array}{c}-0.0002 \\
(0.47)\end{array}$ & $\begin{array}{c}-0.0001 \\
(0.8)\end{array}$ & $\begin{array}{l}-0.0039 \\
(0.03)^{\star *}\end{array}$ \\
\hline Wealth & $\begin{array}{c}-0.0083 \\
(0.29)\end{array}$ & $\begin{array}{c}0.0128 \\
(0.23)\end{array}$ & $\begin{array}{c}0.0231 \\
(0.00)^{* * *}\end{array}$ & $\begin{array}{c}0.0030 \\
(0.22)\end{array}$ & $\begin{array}{c}0.0010 \\
(0.49)\end{array}$ & $\begin{array}{c}0.0026 \\
(0.62)\end{array}$ & $\begin{array}{c}-0.0343 \\
(0.01)^{\star * *}\end{array}$ \\
\hline Farm size & $\begin{array}{c}0.0536 \\
(0.32)\end{array}$ & $\begin{array}{l}0.1176 \\
(0.09)^{*}\end{array}$ & $\begin{array}{l}0.0034 \\
(0.91)\end{array}$ & $\begin{array}{c}0.0077 \\
(0.58)\end{array}$ & $\begin{array}{c}-0.0007 \\
(0.94)\end{array}$ & $\begin{array}{c}0.0030 \\
(0.9)\end{array}$ & $\begin{array}{l}-0.1846 \\
(0.05)^{\star *}\end{array}$ \\
\hline Highly fertile soil & $\begin{array}{c}0.0342 \\
(0.21)\end{array}$ & $\begin{array}{c}0.0314 \\
(0.39)\end{array}$ & $\begin{array}{c}-0.0066 \\
(0.64)\end{array}$ & $\begin{array}{l}0.0125 \\
(0.10)^{*}\end{array}$ & $\begin{array}{l}0.0080 \\
(0.32)\end{array}$ & $\begin{array}{c}-0.0148 \\
(0.33)\end{array}$ & $\begin{array}{c}-0.0648 \\
(0.17)\end{array}$ \\
\hline Infertile soil & $\begin{array}{c}-0.0375 \\
(0.29)\end{array}$ & $\begin{array}{c}-0.0168 \\
(0.73)\end{array}$ & $\begin{array}{l}0.0091 \\
(0.70)\end{array}$ & $\begin{array}{c}0.0176 \\
(0.30)\end{array}$ & $\begin{array}{c}-0.0032 \\
(0.64)\end{array}$ & $\begin{array}{c}0.0471 \\
(0.20)\end{array}$ & $\begin{array}{c}-0.0162 \\
(0.81)\end{array}$ \\
\hline Extension & $\begin{array}{l}0.0434 \\
(0.09)^{\star}\end{array}$ & $\begin{array}{c}-0.0075 \\
(0.80)\end{array}$ & $\begin{array}{l}0.0138 \\
(0.30)\end{array}$ & $\begin{array}{c}0.0052 \\
(0.35)\end{array}$ & $\begin{array}{l}0.0016 \\
(0.73)\end{array}$ & $\begin{array}{c}-0.0027 \\
(0.84)\end{array}$ & $\begin{array}{c}-0.0537 \\
(0.08)^{\star}\end{array}$ \\
\hline Climate information & $\begin{array}{c}-0.0257 \\
(0.32)\end{array}$ & $\begin{array}{l}0.0018 \\
(0.95)\end{array}$ & $\begin{array}{c}-0.0112 \\
(0.43)\end{array}$ & $\begin{array}{c}0.0031 \\
(0.60)\end{array}$ & $\begin{array}{c}-0.0011 \\
(0.82)\end{array}$ & $\begin{array}{c}0.0172 \\
(0.26)\end{array}$ & $\begin{array}{l}0.0161 \\
(0.69)\end{array}$ \\
\hline Credit & $\begin{array}{l}0.0355 \\
(0.06)^{*}\end{array}$ & $\begin{array}{c}0.0289 \\
(0.42)\end{array}$ & $\begin{array}{c}-0.0014 \\
(0.93)\end{array}$ & $\begin{array}{c}-0.0093 \\
(0.19)\end{array}$ & $\begin{array}{l}0.0149 \\
(0.09)^{*}\end{array}$ & $\begin{array}{c}0.0172 \\
(0.37)\end{array}$ & $\begin{array}{c}-0.0858 \\
(0.08)^{\star}\end{array}$ \\
\hline Off-farm employment & $\begin{array}{l}0.0302 \\
(0.27)\end{array}$ & $\begin{array}{c}-0.0046 \\
(0.88)\end{array}$ & $\begin{array}{l}0.0006 \\
(0.96)\end{array}$ & $\begin{array}{c}-0.0077 \\
(0.09)^{\star}\end{array}$ & $\begin{array}{c}0.0339 \\
(0.00)^{\star \star \star \star}\end{array}$ & $\begin{array}{c}0.0074 \\
(0.63)\end{array}$ & $\begin{array}{c}-0.0597 \\
(0.18)\end{array}$ \\
\hline Tenure & $\begin{array}{c}0.0112 \\
(0.63)\end{array}$ & $\begin{array}{c}0.0204 \\
(0.52)\end{array}$ & $\begin{array}{l}0.0102 \\
(0.47)\end{array}$ & $\begin{array}{l}0.0124 \\
(0.10)^{\star}\end{array}$ & $\begin{array}{c}-0.0048 \\
(0.27)\end{array}$ & $\begin{array}{c}0.0466 \\
(0.02)^{* *}\end{array}$ & $\begin{array}{l}-0.0960 \\
(0.03)^{\star *}\end{array}$ \\
\hline Latitude & $\begin{array}{c}0.0404 \\
(0.03)^{\star *}\end{array}$ & $\begin{array}{c}-0.0208 \\
(0.12)\end{array}$ & $\begin{array}{c}-0.0082 \\
(0.10)^{*}\end{array}$ & $\begin{array}{c}0.0074 \\
(0.14)\end{array}$ & $\begin{array}{c}-0.0034 \\
(0.13)\end{array}$ & $\begin{array}{c}0.0020 \\
(0.69)\end{array}$ & $\begin{array}{c}-0.0174 \\
(0.41)\end{array}$ \\
\hline Longitude & $\begin{array}{c}-0.0132 \\
(0.39)\end{array}$ & $\begin{array}{c}-0.0020 \\
(0.91)\end{array}$ & $\begin{array}{c}0.0175 \\
(0.02)^{\star *}\end{array}$ & $\begin{array}{c}0.0060 \\
(0.17)\end{array}$ & $\begin{array}{l}-0.0039 \\
(0.05)^{\star \star}\end{array}$ & $\begin{array}{c}-0.0046 \\
(0.52)\end{array}$ & $\begin{array}{c}0.0002 \\
(0.99)\end{array}$ \\
\hline Rainfall & $\begin{array}{l}0.0005 \\
(0.12)\end{array}$ & $\begin{array}{c}0.0004 \\
(0.16)\end{array}$ & $\begin{array}{l}-0.0003 \\
(0.03)^{\star *}\end{array}$ & $\begin{array}{c}0.0001 \\
(0.36)\end{array}$ & $\begin{array}{c}0.0000 \\
(0.87)\end{array}$ & $\begin{array}{c}-0.0001 \\
(0.68)\end{array}$ & $\begin{array}{c}-0.0006 \\
(0.12)\end{array}$ \\
\hline Temperature & $\begin{array}{l}0.0133 \\
(0.04)^{\star \star}\end{array}$ & $\begin{array}{l}0.0136 \\
(0.09)^{*}\end{array}$ & $\begin{array}{l}-0.0114 \\
(0.00)^{\star \star \star}\end{array}$ & $\begin{array}{c}0.0005 \\
(0.73)\end{array}$ & $\begin{array}{l}0.0005 \\
(0.72)\end{array}$ & $\begin{array}{l}0.0075 \\
(0.07)^{\star}\end{array}$ & $\begin{array}{l}-0.0240 \\
(0.03)^{\star \star}\end{array}$ \\
\hline Probability & 0.09 & 0.12 & 0.035 & 0.01 & 0.01 & 0.035 & 0.7 \\
\hline
\end{tabular}

Notes: ${ }^{* * *}$ significant at $1 \%,{ }^{* *}$ significant at $5 \%,{ }^{*}$ significant at $10 \%$ 
This paper reveals that, although farmers are well aware of long-term climatic trends, few seem to take steps to adjust their farming activities. Farmers in the Limpopo river basin practised switching crops and varieties, changing planting dates, increasing irrigation, building water-harvesting structures, changing land area under cultivation, and buying livestock feed supplements to cope with climate change.

The MNL analyses of determinants of adaptation to climate change indicated that household size, wealth, farm size, farming experience, perception of soil fertility, access to credit, extension and off-farm activities, tenure security, high temperature and low rainfall tend to enhance adaptive capacity regarding climate change.

Government intervention policies are, therefore, needed to ensure that farmers have access to affordable credit to increase their ability and flexibility to change production strategies in response to changing climate conditions. Because access to water for irrigation increases the resilience of farmers to climate variability, irrigation investment needs should be reconsidered to allow farmers increased water control to counteract adverse impacts from climate variability and change. However, to promote efficient water use, emphasis should be given to reform water pricing and clearly defined property rights, as well as strengthening of farmlevel irrigation efficiency. More important is the fact that implementation of the land reform policy has increased the number of new, emerging farmers who did not have the same skills and information compared to their more experienced counterparts. This implies that improved access to extension services is critical for enhancing the adaptive capacity of emerging farmers in South Africa. Study results also suggest that diversification of livelihoods through providing off-farm income and employment opportunities is an important adaptation strategy for rural households.

\section{ACKNOWLEDGEMENTS}

This work was supported by the Federal Ministry for Economic Cooperation and Development, Germany, under the project Food and Water Security under Global Change: Developing Adaptive Capacity with a Focus on Rural Africa, which forms part of the CGIAR Challenge Programme on Water and Food. Support has also been received under the IFPRI DGO Small Grants Initiative Program. The authors would like to thank Kato Edwards, Elizabeth Bryan and Wisdom Akpalu for their assistance on numerous technical points. The views expressed here are the authors' alone. 


\section{NOTES}

* Corresponding author. Fax: +27 12420 4958. E-mail address: gladys.gbetibouo@up.ac.za.

$1 \mathrm{PhD}$ candidate, Center for Environmental Economics and Policy in Africa (CEEPA), Department of Agricultural Economics in Rural Development, University of Pretoria, South Africa.

2 Professor and Director, Center for Environmental Economics and Policy in Africa (CEEPA), Department of Agricultural Economics and Rural Development, University of Pretoria, South Africa, e-mail: rashid.hassan@up.ac.za.

3 Senior Researcher, Environmental and Protection Technology Division, International Food Policy Research Institute (IFPRI), e-mail: c.ringler@cgiar.org.

4 Other adaption measures: (1) implement soil conservation techniques; (2) put trees for shading; (3) change from crops to livestock; (4) reduce number of livestock; (5) migrate to urban areas; and others.

5 Following Filmer and Pritchett (2001), principal component analysis (PCA) was used to assign weights to each asset. The overall wealth index is calculated by applying the following formula:

$$
w_{j}=\sum_{i=1}^{k}\left[b_{i}\left(a_{j i}-x_{i}\right)\right] / s_{i}
$$

where $w$ is the wealth index, $b$ the weight from PCA 1, $a$ is the asset value, $x$ is the mean asset value and $s$ is the standard deviation of the assets.

\section{REFERENCES}

Adesina, A.A. and Forson, J.B. 1995. Farmers' perceptions and adoption of new agricultural technology: Evidence from analysis in Burkina Faso and Guinea, West Africa. Agricultural Economics 13, 1-9.

Belliveau, S., Bradshaw, B., Smit, B., Reid, S., Ramsey, D., Tarleton, M. and Sawyer, B. 2006. Farm-level adaptation to multiple risks: Climate change and other concerns. Occasional paper No. 27. Canada: University of Guelph.

Bradshaw, B., Dolan, H. and Smit, B. 2004. Farm-level adaptation to climatic variability and change: crop diversification in the Canadian Prairies. Climatic Change 67, 119-141.

Brklacich, M., McNabb, D., Bryant, C. and Dumanski, I. 1997. Adaptability of agriculture systems to global climate change: A Renfrew County, Ontario, Canada pilot study. In: B. Iibery, Q. Chiotti and T. Richard, eds. Agricultural restructuring and sustainability: A geographical perspective. Wallingford: CAB International.

Bryant, R.C., Smit, B., Brklacich, M., Johnston, R.T., Smithers, J., Chiotti, Q. and Singh, B. 2000. Adaptation in Canadian agriculture to climatic variability and change. Climatic Change 45, 181-201.

Caviglia-Harris, J. 2002. Sustainable Agricultural Practices in Rondônia, Brazil: Do Local Farmer Organizations Impact Adoption Rates? Department of Economics and Finance, Salisbury University. 
Daberkow, S.G., and McBride, W.D. 2003. Farm and Operator Characteristics Affecting the Awareness and Adoption of Precision Agriculture Technologies in the U.S. Precision Agriculture. 4, 163-177.

De Groote, H. and Coulibaly, N. 1998. Gender and Generation: An Intra-Household Analysis on Access to Resources in Southern Mali. African Crop Science Journal 6(1), 79-95.

Deressa, T.T., Hassan, R.M., Ringler, C., Alemu, T. and Yusuf, M. 2009. Determinants of farmers' choice of adaptation methods to climate change in the Nile Basin of Ethiopia. Global Environmental Change 19, 248-255.

Easterling, W.E., Crosson, P.R., Rosenberg, N.J., McKenney, M.S., Katz, L.A. and Lemon, K.M. 1993. Agricultural impacts of and responses to climate change in the Missouri-IowaNebraska region. Climatic Change 24 (1-2), 23-62.

El-Osta, H. and Morehart, M. 1999. Technology adoption decisions in diary production and the role of herd expansion. Agricultural and Resource Economics Review 28(1), 84-95.

Filmer, D. and Pritchett, L.H. 2001. Estimating wealth effects without expenditure data - or tears: An application to educational enrolments in States of India. Demography 38(1), 115-131.

Granjon, D. 1999. Enquêtes et résultants sur l'adaptation de l'agriculture aux différent types de stress: le cas de la zone de Napierville, Research report submitted to B. Singh and C.R. Bryant as part of a Research contract with Atmospheric Environment Services, Environment Canada, Downsview.

Greene, W.H. 2003. Econometric analysis. 5th ed. Upper Saddle River, NJ: Prentice-Hall.

Hansen, D., Erbaugh, J. and Napier, T. 1987. Factors Related to Adoption of Soil Conservation Practices in the Dominican Republic. Journal of Soil and Water Conservation 42, 367-369.

Hausman, J.A. 1978. Specification Tests in Econometrics. Econometrica 46(6), 1251-1271.

IPCC. 2001. Climate Change 2001: Impacts, Adaptation, and Vulnerability. Cambridge University Press.

Lutz, E., Pagiola, S. and Reiche, Y.C. 1994. The Costs and Benefits of Soil Conservation: The Farmer's Viewpoint. The World Bank Research Observer 9, 273-295.

Maddison, D. 2006. The perception of and adaptation to climate change in Africa. CEEPA Discussion Paper No. 10. Centre for Environmental Economics and Policy in Africa, University of Pretoria.

McNamara, K.T., Wetzstein, M.E. and Douce, G.K. 1991. Factors affecting peanut producer adoption of integrated pest management. Review of agricultural economics 13, 129-139.

Mendelsohn, R. 1998. Climate-change damages. In: W.D. Nordhaus, ed. Economics and policy issues in climate change. Resources for the Future: Washington, D.C.

Napier, T. 1991. Factors Affecting Acceptance and Continued Use of Soil Conservation Practices in Developing Societies: A Diffusion Perspective. Agriculture, Ecosystems and Environment $36,127-140$.

Nhemachena, C. and Hassan, R. 2007. Micro-level analysis of farmers' adaptation to climate change in Southern Africa. IFPRI Discussion Paper No. 00714. International Food Policy Research Institute, Washington, D.C.

O’Brien, K., Sygna, L., Naess, L.O., Kingamkono, R. and Hochobeb, B. 2000. Is information enough? User responses to seasonal climate forecasts in Southern Africa. Report 2000, 3. Center for International climate and Environmental Research (CICERO), Oslo. 
Quisumbing, A., Haddad, L. and Peña, C. 1995. Gender and Poverty: New Evidence from 10 Developing Countries. FCND Discussion Paper No. 9, International Food Policy Research Institute, Washington, D.C.

Reilly, J. and Schimmelpfennig, D. 1999. Agricultural impact assessment, vulnerability and the scope for adaptation. Climatic change 43, 745-788.

Rosenzweig, C. and Parry, M.L. 1994. Potential impact of climate-change on world food supply. Nature 367, 133-138.

Saín, G. and Barreto, H.J. 1996. The Adoption of Soil Conservation Technology in El Salvador: Linking Productivity and Conservation. Journal of Soil and Water Conservation 51, 313321.

Shiferaw, B. and Holden, S. 1998. Resource degradation and adoption of land conservation technologies in the Ethiopian Highlands: A case study in Andit Tid, North Shewa, Agricultural Economics, 18, 233-247.

Shultz, S., Faustino, J. and Melgar, D. 1997. Agroforestry and Soil Conservation: Adoption and Profitability in El Salvador. Agroforestry Today 9, 16-17.

Smit, B. and Skinner, M.W. 2002. Adaptations options in agriculture to climate change: A typology. Mitigation and Adaptation Strategies for Global Change 7, 85-114.

Smit, B., McNabb, D. and Smithers, J. 1996. Agricultural adaptation to climatic variation. Climatic Change 33, 7-29.

Smith, J.B., 1996. Using a decision matrix to assess climate change adaptation. In J.B. Smith, N. Bhatti, G. Menzhulin, R. Benioff, M.I. Budyko, M. Campos, B. Jallow and F. Rijsberman, eds. Adapting to climate change: An international perspective. New York: Springer.

Teklewold, H., Dadi, L., Yami, A. and Dana, N. 2006. Determinants of adoption of poultry technology: A double-hurdle approach. Livestock Research for Rural Development 18 Article 40. Available from http://www.lrrd.org/lrrd18/3/tek118040.htm. ( accessed on 21 July 2008).

Tizale, C.Y. 2007. The dynamics of soil degradation and incentives for optimal management in the Central Highlands of Ethiopia. PhD thesis. Faculty of Natural and Agricultural Sciences, University of Pretoria.

Wall, E. and Smit, B. 2005. Climate change adaptation in light of sustainable agriculture. Journal of Sustainable Agriculture 27(1), 113-123.

Wozniak, G.D. 1984. The adoption of interrelated innovations: A human capital approach. Review of Economics and Statistics 66 (LXVI), 70-79. 